\title{
CHARITY: THE DIVINE SCIENCE OF ALLAH SWT
}

\author{
Zin Eddine Dadach \\ Department of Chemical and Petroleum Engineering, Abu Dhabi Men's College \\ Higher Colleges of Technology (HCT) \\ St \# 19, Muroor Road, Al Saada Street, Al Nahyan - Abu Dhabi - Uni Emirat Arab \\ E-mail: zdadach@hct.ac.ae
}

\begin{abstract}
The purpose of this investigation is an attempt to perceive the divine science in nature based on some Quranic verses and a spiritual interpretation of movements in nature. First, based on the Quranic verse (55:7), it is understood that Allah SWT urges the regions rich in energy to give part of this richness to the regions poor in energy in order to create a balance and harmony in nature. This is described in this investigation as the $1^{\text {st }}$ divine law of charity of the Divine Science. From the second Quranic verse (15:21), which is described as $2^{\text {nd }}$ divine law of charity of the Divine Science, Allah SWT also fixes the amount of the matter or energy to be flowing from a rich region to a poor region. Using the water cycle as an example to sense the divine science, it is perceived that the divine purpose of the oceans is to use solar energy in order to generate a certain flow of water vapor, predetermined by Allah SWT, as charity to the dry skies over the seas and oceans. Moreover, the divine duty of the skies over the seas and oceans is to utilize the power of wind in order to offer a certain part of that flow of water, predesignated by Allah SWT, as charity to the dry skies over the lands. Finally, the divine purpose of the skies over lands is to use the earth's gravity in order to offer a portion of water as rain or snow, predestined by Allah SWT, as charity to the dry land.
\end{abstract}

Keywords: charity, dynamic systems, Islam, second law of thermodynamics, water cycle

Abstrak: Tujuan penelitian ini adalah upaya untuk memahami ilmu ketuhanan di alam berdasarkan beberapa ayat Alquran dan interpretasi spiritual dari gerakan di alam. Pertama, berdasarkan ayat Alquran (55: 7), dipahami bahwa Allah SWT berkeinginan daerah-daerah yang kaya energi memberikan sebagian kekayaan tersebut kepada daerah-daerah yang miskin energi guna menciptakan keseimbangan dan keharmonisan alam. Hal ini dijelaskan dalam penelitian ini sebagai hukum ilahi pertama sebagai ilmu kasih Ilahi. Dari ayat Alquran kedua (15:21), yang digambarkan sebagai hukum kasih Ilahi ke-2, Allah SW'T juga menetapkan jumlah materi atau energi yang akan mengalir dari daerah kaya ke daerah miskin. Dengan menggunakan siklus air sebagai contoh untuk merasakan ilmu ketuhanan, dianggap bahwa tujuan ilahi pada lautan adalah untuk mengakomidir energi matahari dengan menghasilkan aliran uap air tertentu, yang telah ditentukan oleh Allah SWT sebagai kebaikan kepada langit kering yang mengitari lautan dan samudra. Di samping itu, tugas ilahi pada langit yang mengitari lautan dan samudra adalah memanfaatkan kekuatan angin untuk mendorong aliran air, yang telah ditentukan sebelumnya oleh Allah SWT, sebagai suatu kebaikan untuk langit yang kering di atas daratan. Yang terakhir adalah tujuan ilahi dari langit yang mengitari daratan untuk menggunakan gravitasi bumi yang mampu mengakomodir air sebagai hujan atau salju, yang telah ditentukan oleh Allah SWT, sebagai kebaikan kepada tanah kering di daratan.

Kata Kunci: hukum ternodinamika kedua, Islam, kebaikan, siklus air, sistem dinamis

\section{Introduction}

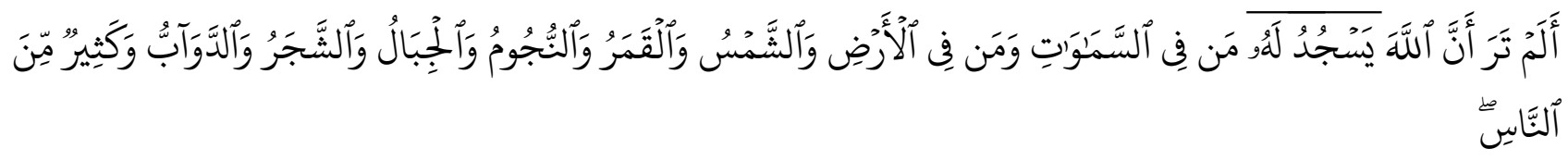

Meaning:

"See you not that whoever is in the heavens and whoever is on the earth, and the sun, and the moon, and the stars, and the mountains, and the trees, and living creatures, beasts and many of mankind prostate themselves to Allah..." (QS. AlHajj: 18)

This Quranic verse aroused my curiosity in order to find the commonality in the commandments of Allah SWT related to the universe and human beings and encouraged me to search for the type of commandment. For the humanity (Khan, 1996), in the Quranic verse, 


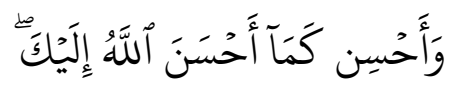

Meaning:

"And do good as Allah has been good to you" (QS. Al-Qasas: 77)

Allah SW'T asks us to show our intention to please Him by sharing part of the wealth He provided to us with the less fortunate. From this perspective, the Arabic word Zakat means to self-purify our soul. Therefore, the intention of every rich person to self-purify his/her soul is to help the poor. For this divine obligation, the amount of charity is fixed at $2.5 \%$ of a Muslim's total savings and wealth above a minimum amount (nisab) is donated annually (al Qardawi, 2008).

In addition to this duty, we can have the opportunity to self-purify our soul and add good deeds by giving whatever we can as cited in the Quran,

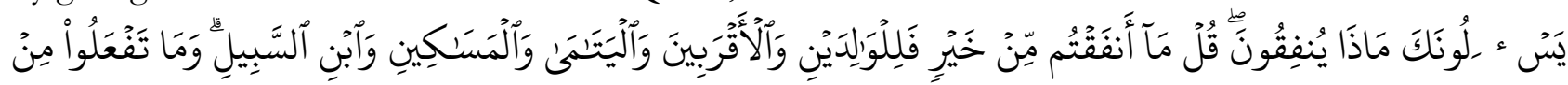

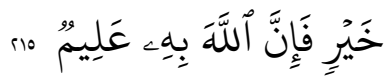

Meaning:

"They ask. you (O Muhammad) what they should spend. Say: Whatever you spend of good must be for parents and kindred and orphans and the needy and for wayfarers, and whatever you do of good deeds, Allah knows it well" (QS. Al-Baqarah: 215).

Therefore, the intention to please Allah SWT and self-purify our soul is not limited to only helping those in need by giving them money or food to survive, but encompasses acts of charity during our social activities such as offering assistance and time to relatives, neighbors and friends as well as those who are unwell to comfort them and perhaps add some joy to their life, or enhance it in some way. Finally, we are also supposed to please Allah SWT during our professional activities by sharing all what He has taught us. For example, the charity of an engineer (rich in knowledge) is to offer expertise to properly solve technical problems. The divine purpose of a doctor (rich in knowledge) is to treat patients adequately and provide them with the proper diagnosis and treatment and the divine responsibility of a teacher (rich in knowledge) is to impart knowledge and enable students to learn.

\section{A. The importance of science in Islam}

It seems like Allah SWT created the universe as a universal school for humanity in order to contemplate it to perceive His lessons and thank Him for all His Favors. For example, through the change of nature over the four seasons, Allah SWT teaches us several lessons and also reminds us of His Blessings. Indeed, the transformation of the weather during the four seasons shows how Allah SWT has coordinated the rotations of earth, the moon and the sun in order to make our life change through variations of feelings to avoid boredom. In this perspective, Earth, which is the third planet from the sun, continuously rotates over twenty-four hours. According to this rotation, we have days and nights on earth, we have daylight for the part of earth that is facing the sun and it is dark for the other part of earth. Moreover, as mentioned in the two Quranic verses,

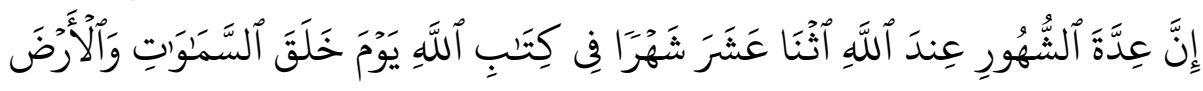

Meaning:

"Verily, the number of months with Allah is twelve months (in a lunar year) so it was ordained by Allah on the day when He created the heavens and the earth" (QS. At Taubah: 36) (Khan, 1996).

and the verse,

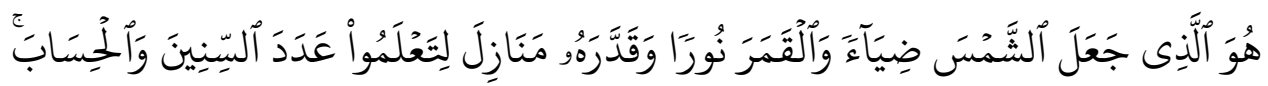

Meaning:

"It is He Who made the sun a shining thing and the moon as a light and measured out for in stages that you might know the number of years and the reckoning"'(QS. Yunus: 5).

There are twelve months in one lunar year and we can count days, weeks, months and years with the size of the crescent and the moon. 
According to Mr. Shamsher Ali, there are around 750 verses in the Quran dealing with natural phenomena. This Quranic verse,

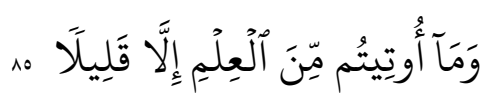

Meaning:

"And of knowledge, you mankind have been given only a little" (Al-Isra: 85) (Khan, 1996).

Moreover, I consider as an inspiration for the acquisition of new knowledge. For some Muslim writers, the study of science stems from Al-Tawheed (Ikbal, 2007). This could be interpreted as only one divine science is governing the whole universe. In this perspective, my efforts (Ijtihad) in this investigation is to search for the Quranic verses that could lead me to the Divine Science (Ali, 2018).

The conception of knowledge (Al-Ilm) in Islam is the Guiding Light (Huda) separating right from wrong (Al furqan). Therefore, in the same way, the sun brings light to our eyes to see the world around us, Al-Ilm is the source of guidance to see the Truth. The sacred position of knowledge in Islam is also proven by the fact that the word "science" and its derivations appear 779 times (averaging 7 times a chapter) in the Quran (Elsergany, 2011). This is the second position after the word "Allah". The Prophet PBUH was then selected to educate his followers and all humanity in order to erase their ignorance with knowledge. In order to highlight the importance of knowledge to humanity, the first Quranic verse sent to Prophet Muhammad PBUH by Allah SWT through Angel Gabriel started with (Khan, 1996):

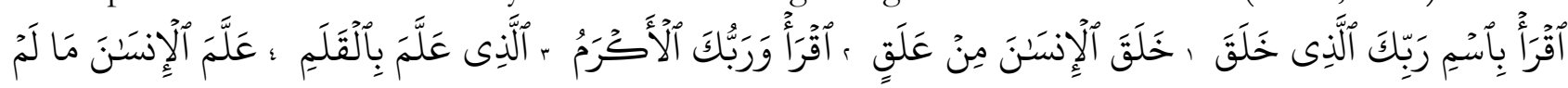

Meaning:

"Read! In the Name of your Lord Who has created all that exists. He has created man from a clot. Read! And Your Lord is the Most Generous who has taught by the pen. He has taught man that which you knew not" (QS. Al 'Alaq: 1$5)$.

To understand the universe, scientists around the planet have tried to find some universal laws such as statements that describe or predict a range of natural phenomena in the universe. In the perspective, Allah SW'T exhorts Muslims to observe and study the universe in order to find some marks of His signs. For that reason, many verses of the Quran ask Muslims to study nature, and this has been interpreted to mean encouragement for scientific inquiry.

\section{B. First divine law of charity}

Regarding the Quranic verse:

Meaning:

"And the heaven He has raised high, and has set up a Balance" (QS. Ar-Rahman: 7).

Allah SWT created earth as a sphere and the sun heats equatorial regions more than polar regions. Consequently, some regions in the planet are abundant in energy and other regions are deficient in energy (Kushnir, 2008). This uneven distribution of solar radiation is responsible for the imbalance of energy around the planet. According to this first Quranic verse, one can understand that Allah SWT has imposed some divine laws in order to set up a balance on earth. Because He is "The Impartial Judge" and "The Wise One" SWT, this equilibrium is established by driving matter and energy to move from places on earth which have "concentrated" energy to regions on earth with "diluted" energy. This divine commandment is commonly known by physicists as the $2^{\text {nd }}$ law of thermodynamics. Indeed, this law states that heat can be transferred only from higher temperatures to lower temperatures, fluids can flow only from higher pressures to lower pressures and rainfalls from the sky to earth. Since this law is related to flows in nature, this aspect of the $2^{\text {nd }}$ law of thermodynamics is defined in this book as the $1^{\text {st }}$ universal law of dynamic systems and can simply be written as: 


$$
E_{\text {High }}(\text { concentrated }) \stackrel{\text { displacement }}{\longrightarrow} E_{\text {low }}(\text { diluted })
$$

Meaning:

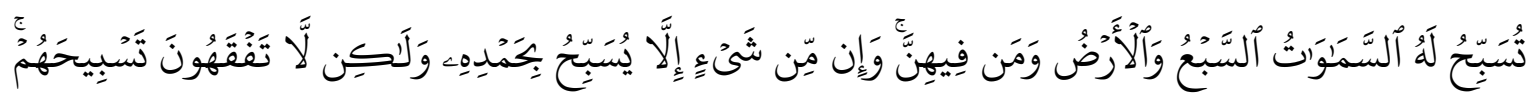

"The seven heavens and the earth and all that is therein, glorify Him and there is not a thing but glorifies His Praise. But you understand not their glorification" (QS. Al Isra': 44).

Moreover, considering energy as a richness and based on the Quranic verse, flows in the dynamic earth are therefore moving from a region rich (concentrated) in energy to a region poor (diluted) in energy. My spiritual vision of this physical phenomena tells me that "The Just One" SWT established a balance in the universe by imposing on places on earth rich in energy provided by Him using the sun, to share part of their richness with the regions of earth poor in energy. Consequently, every single space rich in energy is glorifying Allah SWT by sharing part of its richness (energy) in order to respect the balance imposed by Allah SWT on earth. From this spiritual interpretation of movements in nature, the $1^{\text {st }}$ universal law of dynamic systems is defined in this paper as the $\mathbf{1}^{\text {st }}$ divine law of charity imposed by Allah SWT on the universe. As a result, equation (1) of dynamic systems becomes:

$$
\text { Rich (in energy) } \stackrel{\text { Divine Flow of Charity }}{\longrightarrow} \text { Poor(in energy) }
$$

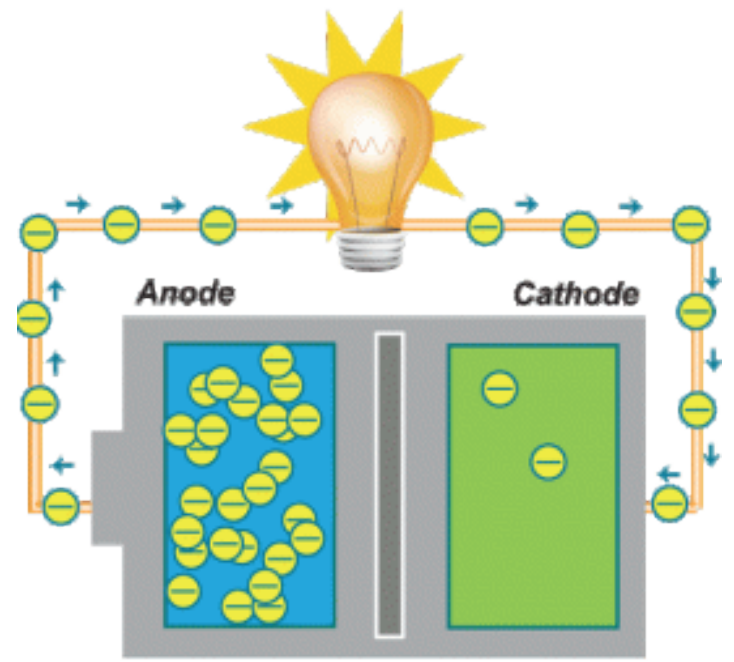

Figure 1. Electrical battery (Source: Riddle, 2016)

As shown in Figure 1, a typical example of the $1^{\text {st }}$ divine law of charity is that the anode (rich in electrons) of an electrical battery is urged to give some electrons to the cathode (poor in electrons). In this case, the scientific explanation of the $1^{\text {st }}$ divine law of charity is called the Electromotive force (Emf), which is defined as the characteristic of any "energy source" capable of moving electrons inside an electrical circuit.

\section{The second divine law of charity}

Secondly, from this Quranic verse:

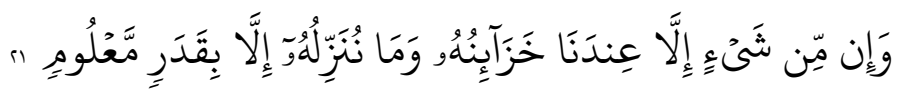


Meaning:

"And there is not a thing but that with Us are its depositories, and We do not send it down except according to a known measure" (QS. Al-Hijr: 21).

Everything transported in the universe has a fixed measure determined by "The All Authoritative One" SWT. Therefore, natural flows obey Allah SWT by always moving from places of "rich energy" to places of "poorer in energy", and additionally their quantity and timing are also predestined by a second divine commandment.

Meaning:

"And we sent down from the sky water (rain) in (due) measure" (QS. Al-Mu'minun: 18).

For example, according to the Quranic verse (Khan, 1996), the amount of rain or snow (water) that falls, and its timing are predetermined by Allah SW'T. My efforts to find a scientific expression to this second Quranic verse (15: 21) started in 1984, when I returned to Algeria from the USA in order to teach at the Algerian Petroleum Institute. It was explained to the students that a flow is mathematically proportional to its driving force and inversely proportional to its resistance and the following qualitative general equation of dynamic systems was introduced:

$$
\text { Flow } \propto \frac{\text { Driving Force }}{\text { Resistance }}
$$

In order to relate this general equation to the Quranic verse (15:21), the difference in energy between a region in earth having high energy $\left(\mathrm{E}_{\mathrm{High}}\right)$ and a region having low energy $\left(\mathrm{E}_{\text {low }}\right)$ is considered as the "driving force" of any natural process and, the fluid or solid between these two regions presents a resistance " $R$ " to the flow under consideration. Based on Equation (3), the predetermined flow of matter or energy transported could be qualitatively represented by:

$$
\text { Flow }\left(\frac{\text { Amount of mater or energy }}{\text { time }}\right) \propto \frac{\left(E_{\text {High }}-E_{\text {low }}\right)}{R}
$$

Equation (4) is defined in this paper as the qualitative approach of the $2^{\text {nd }}$ universal law of dynamic systems that deals with the amount of matter or energy to be transferred. In concordance with the $1^{\text {st }}$ divine law of charity, Equation (4) is also the $2^{\text {nd }}$ divine law of charity. Looking spiritually in the direction of the arrow in Figure 2, it could be perceived that heat $(\mathrm{Q})$ is flowing from the hot part of the material "rich" in thermal energy $\left(T_{2}>T_{1}\right)$ to the cold part of the metal "poor" in thermal energy.

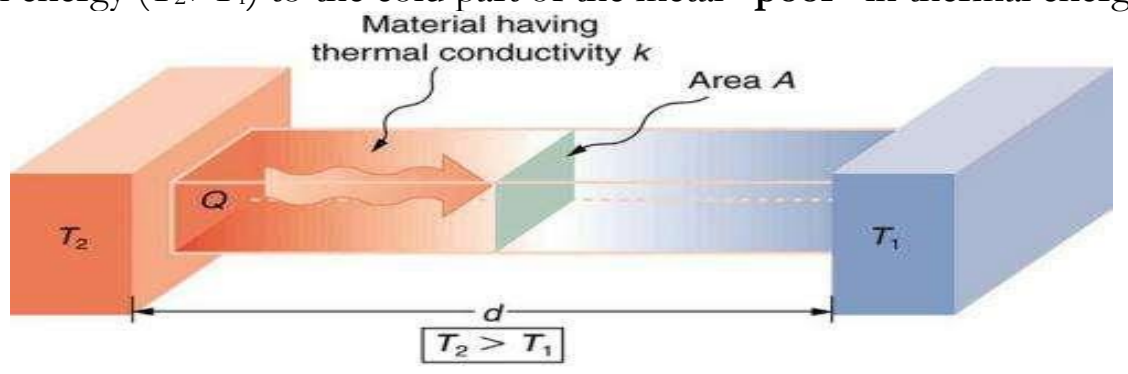

Figure 2. Heat transfer by conduction (Source: Williams, 2014)

Furthermore, as shown in Figure 2, the "gradient of richness" of heat (Q) is the difference in temperature $\left(T_{2}-T_{1}\right)$ between the two parts of the material. If $\mathbf{k}$ is the thermal conductivity of the material, $(1 / \mathbf{k})$ is therefore the resistance to the heat flow $(\mathrm{Q})$. Based on the $2^{\text {nd }}$ divine law of charity, the amount of richness $(\mathrm{Q})$ given as charity can be qualitatively expressed by Equation (5) as:

$$
\text { Flow of richness }\left(\frac{Q}{t}\right) \propto \frac{\left(T_{2}-T_{1}\right)^{\prime \prime} \text { Driving Force" }}{\left.\left(\frac{1}{k}\right)\right)^{\prime R e s i s t a n c e "}}
$$


Consequently, the second lesson to learn from meditating in nature is that Allah SWTimposes on every rich entity a requirement to share a prefixed amount of its richness with the poor in order to create justice and harmony between them. As described in Equation (6), Fourier's law is the quantitative expression of the amount of heat $(\mathrm{Q})$ prefixed by the $2^{\text {nd }}$ divine law of charity:

$$
\text { Heat flow }\left(\frac{Q}{t}\right)=\frac{\left(T_{2}-T_{1}\right)}{t / k A}
$$

Other examples of the scientific illustration of the $2^{\text {nd }}$ divine law of charity are Fick's law in the Chemical Engineering field which measures the flow of matter conveyed by mass transfer by diffusion and Ohm's law in the electrical engineering field which is related to the flow of electrons.

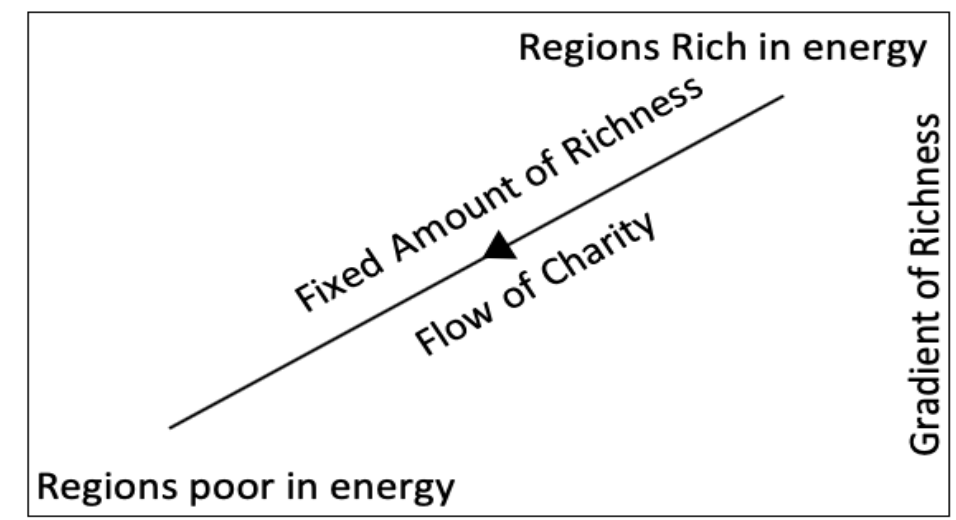

Figure 3. The Laws of the Divine Science (Source: Author's Figure)

In conclusion, the $1^{\text {st }}$ Quranic verse (55:7) taught me that in order to create a balance and harmony in nature, Allah SW'T urges the regions rich in energy to give part of richness to the regions poor in energy. This is described in this book as $1^{\text {st }}$ divine law of charity of the Divine Science. From the second Quranic verse (15:21), which is described as $2^{\text {nd }}$ divine law of charity of the Divine Science, Allah SWT fixes the amount of the matter or energy to be flowing from a rich region to a poor region (Figure 3).

\section{Signs of charity in the water cycle}

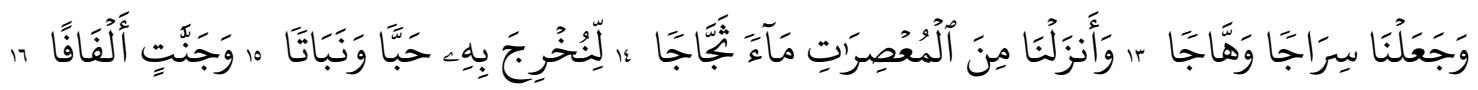

Meaning:

"And We have made a shining lamp (sun). And We have sent down from the rainy clouds abundant water that We may produce therewith corn and vegetation and gardens of thick growth" (QS. An-Naba': 13-16) (Khan, 1996).

Because of the existence of water, the earth is unique among the other known celestial bodies. Indeed water covers three-fourths of its surface and constitutes $60-70 \%$ of the living world. At a micro level, the human body consists of more than $70 \%$ water (Khan, 2019). The most amazing aspect about the divine science is that Allah SWT created water with some properties that allow it to regenerate and to be redistributed through evaporation and condensation in order to be endlessly renewable. The different stages of the water cycle (Figure 4) are therefore selected in this paper because they are the demonstration that water is an infinitely renewable source of life. We can also perceive how natural flows in the water cycle obey the divine laws of charity during the four seasons of the year. 


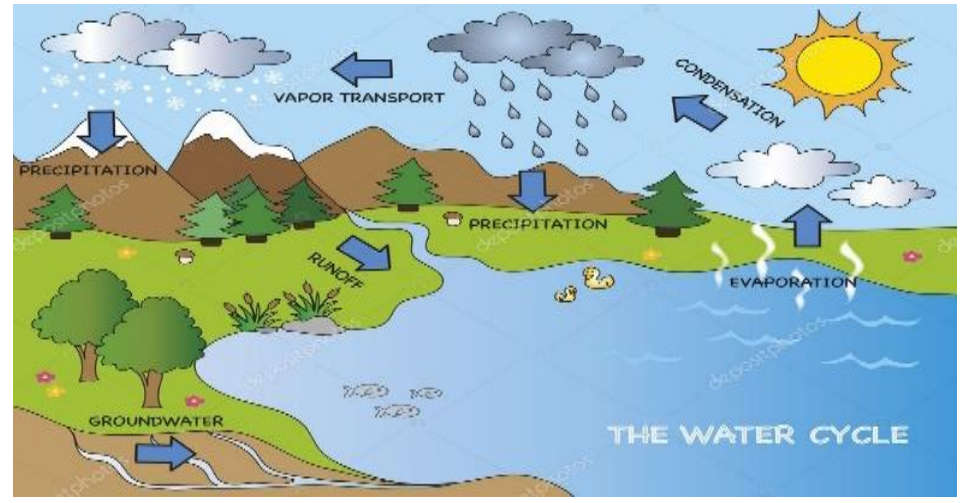

Figure 4: The water cycle (Source: Global Climate Team, 2014)

\section{E. Evaporation of water using solar radiation}

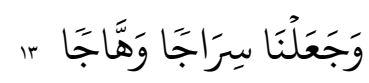

Meaning:

"And We have made (therein) a shining lamp (sun)" (QS. An-Naba': 13).

For this first step of the water cycle, the $1^{\text {st }}$ divine law of charity is fulfilled since the partial pressure of water vapor at the sea level has the highest value $\left(\mathrm{P}_{\mathrm{w}}\right.$, sea $)$ and decreases slowly to its lowest value $\left(\mathrm{P}_{\mathrm{w}}\right.$ sky) located in the sky. To apply the $2^{\text {nd }}$ divine law of charity, the gradient of richness $\left(\mathrm{P}_{\mathrm{w} \text {, sea }}-\mathrm{P}_{\mathrm{w} \text {, sky }}\right)$ between sea level and the sky is considered as the "driving force" of the evaporation process of water. Moreover, using the convective mass transfer coefficient $\left(\mathrm{k}_{\mathrm{air}}\right)$ of atmospheric air, the flow of evaporation of water is regulated by the resistance to mass transfer $\left(1 / \mathrm{k}_{\text {air }}\right)$ of the atmospheric air. Therefore, the flow of water evaporated is qualitatively expressed by the equation:

$$
\text { Natural Flow }(W E) \propto \frac{\left(P_{w . s e a}-P_{w, s k y)}\right.}{\left(\frac{1}{k_{\text {air }}}\right)}
$$

In order to calculate the flow (WE), scientists in hydrometeorology use the Penman equation. The equation is based on measurements of the mean temperature of sea, wind speed, air pressure, and solar radiation (Zotarelli et al., 2018).

\section{F. Transportation of vapor using wind power}

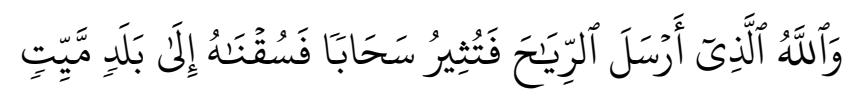

Meaning:

"And it is Allah Who sends the winds, so they can raise up the clouds, and We drive them to a dead land" (QS. Fàtir: 9).

This second stage of the water cycle will obey the $1^{\text {st }}$ divine law of charity when air over oceans will have higher values of atmospheric pressure $\left(\mathrm{P}_{\text {High }}\right)$ than the atmospheric pressure $\left(\mathrm{P}_{\text {low }}\right)$ of air over land. Moreover, in order to utilize the $2^{\text {nd }}$ divine law of charity, the gradient of richness $\left(\mathrm{P}_{\text {High }}-\mathrm{P}_{\text {low }}\right)$ is taken as the driving force of the transportation process of water. The flow of water transported is also regulated by the friction $\left(\mathrm{R}_{\text {air }}\right)$ caused by atmospheric air. Therefore, similar to the evaporation process, the flow of water transported by the winds (W'T) could be qualitatively expressed by the equation:

$$
\text { Natural Flow }(W T) \propto \frac{\left(P_{\text {High }} P_{\text {low }}\right)}{R_{\text {air }}}
$$

The flow (WT) transported is usually quantified using the advection equation where and the two most important parameters that affect the process are the strength and the angle of the wind (Gallana et al., 2014). 


\section{G. Precipitation of rain using earth's gravity}

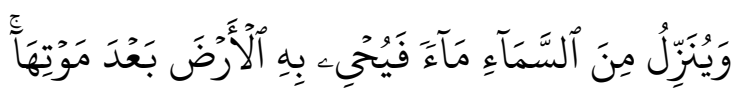

Meaning:

"He sends down water (rain) from the sky, and therewith revives the earth after its death" (QS. Ar-Rum: 24).

The last stage of the water cycle is bowing to the 1st divine law of charity because the water contained in heavy clouds has the highest value of potential energy $\left(\mathrm{PE}_{\mathrm{High}}\right)$ and the value of their potential energy ( $\left.\mathrm{PE}_{\text {low }}\right)$ is lowest at the ground level. For the $2^{\text {nd }}$ divine law of charity, the gradient of richness ( $\left.\mathrm{PE}_{\text {high }}-\mathrm{PE}_{\text {low }}\right)$, caused by earth's gravity, is therefore the driving force of the precipitation process of water. It should be noted that the "The Merciful" SWT created air with a resistance $\left(\mathrm{R}_{\text {air }}\right)$ that controls the speed of precipitation of the droplets of water. Without this resistance, rain could destroy vegetation and harm people as well as animals and other living things. Finally, the flow of water (rain or snow) falling could be qualitatively described by the equation:

$$
\text { Natural Flow }(W F) \propto \frac{\left(P E_{\left.H i g h-P E_{l o w}\right)}\right.}{R_{\text {air }}}
$$

This amount (WF) is usually calculated by the intensity of rainfall which indicates the amount of rain that falls over time and it is measured in millimeters per hour $(\mathrm{mm} / \mathrm{h})($ Lanza et al., 2010).

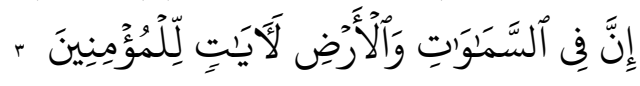

Meaning:

"Verily, in the heavens and the earth are signs for the believers" (QS. Al-Jatsiyah: 3).

Based on this Quranic verse and contemplating the arrows in Figure 4 from a spiritual perspective, it could be concluded that, respecting the balance imposed by Allah SWT on the universe, the direction of the flows in the water cycle is from a region rich in energy to a region poor in energy. This is a clear sign of obedience of nature to the $1^{\text {st }}$ divine law of charity as indicated in the first Quranic verse (55:7). For the $2^{\text {nd }}$ divine law of charity, as mentioned in the other Quranic verse (15:21) under study, the divine purpose of the oceans is to use solar energy in order to generate a certain flow of water vapor (WE), predetermined by Allah SWT, as charity to the dry skies over the seas and oceans. Following this step, the sky over the oceans becomes rich enough in water. It has then the divine duty to utilize the power of wind in order to offer a certain part of that flow of water WT, predesignated by Allah SWT, as charity to the dry skies over the lands. Finally, when the sky over the land also gets rich enough in water (heavy clouds), its divine purpose is to use the earth's gravity in order to offer a portion of water as rain or snow (WF), predestined by Allah SWT, as charity to the dry land. In conclusion, since nature was created to be a universal school for humanity and as mentioned in the Quranic verses (55:7 and 15:21), all the natural flows are fulfilling the two divine laws of charity imposed by Allah SWT.

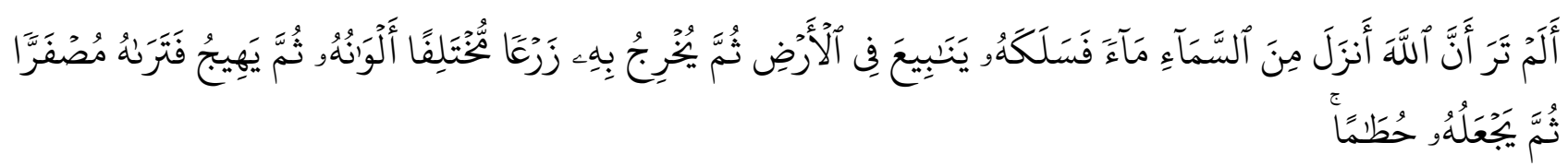

Meaning:

"See you not that Allah sends down rain (rain) from the sky, and causes it to penetrate the earth, as water springs, and afterward thereby produces crops of different colours; and afterward they wither and you see them turn yellow then He makes them dry and broken piece" (QS. Az-Zumar: 21).

Indeed, after the hot summer, a windy autumn and a cold winter, nature seems happy during the lovely spring. By His Beautiful Names "The Bountiful One" and "The Sustaining One", it is a time of abundance and regeneration, with birds singing and flowers blooming. 


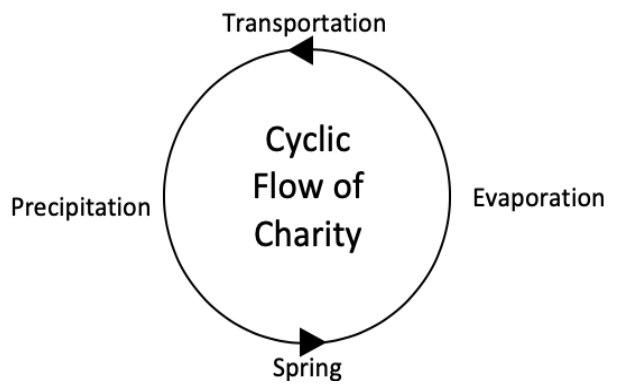

Figure 5: Cyclic flow charity and spring (Source: Author's Figure)

My spiritual thought teaches me that spring is a reward of Allah SWT to every single thing in nature after a Cyclic Flow of Charity (Figure 5). At the end of this paradisiac spring, nature seems to lose balance as the cycle of charities start again.

\section{Conclusion}

The most important lesson learned is that Allah SW'T used nature as a universal school in order to show us that His science is based on charity for the purpose to create balance and harmony. Based on the two Quranic verses (55:7 and 15:21) used to perceive the divine science and a spiritual view of movements in nature, I came also to understand that Allah SWT installs balance both between different regions of earth by establishing two divine laws of charity in order to create justice between the rich and the poor and harmony in the universe. In conclusion, since nature was created to be a universal school for humanity and as mentioned in the Quranic verses (55:7 and 15:21), all the natural flows are fulfilling the two divine laws of charity imposed by Allah SWT.

Similar to nature, divine laws of charity for Muslims are also indicated in the Quran. There is therefore a complete harmony between the signs of Allah SWT in nature, scientifically described by universal laws and His words in the Holy Quran. For instance, after the gestures of charity perceived during the summer, autumn and winter, the reward is the beauty of the deserved spring. This reward of the Cyclic Flow of Charity is a sign that comes every year as a lesson for humanity. However, spirituality is needed in Islam in order to be able to perceive that Allah SWT governs everything behind the stage of the visible material world.

On a last note, Muslim schools are needed in order to teach natural and social sciences under the umbrella of the Divine Science with the Light of the Holy Quran and The Prophet PBUH's sayings. This could be done by integrating Quranic verses and the Prophet PBUH's sayings in the corresponding chapters of the textbooks and the teaching material. For this goal, teachers should have not only the expertise in their field of science but also a good knowledge of the explanation of the Quran and The Prophet PBUH' sayings. As a result, scientific research will not be conducted for the benefits of some rich individuals but for the benefit of all humanity. Moreover, new scientific knowledge will be developed as a means to search for the Truth that brings us closer to Allah SWT.

\section{References}

al Qardawi, Yusuf. 2008. "A Comparative Study of Zakah, Regulations and Philosophy in The Light of Qur'an and Sunnah.” Figh al Zakah 1.

Ali, Shamsher. 2018. “Science and The Qur'an.” In Oliver Leaman. The Qur'an: An Encyclopedia

Elsergany, Ragheb. 2011. "Contributions of Muslims to The World in Islam Story." https://islamstory.com/index.php/en/artical/3407593.

Gallana, L., S. D Savino, F. D. Santi, M. Iovieno and D. Tordella. 2014. "Energy and Water Vapor Transport across a Simplified Cloud-Clear Air Interface.” Journal of Physics: Conference Series 547.

Global Climate Team. 2014. Image ID: 42514881. Copyright: Casaltamoiola.

Iqbal, Muzaffar. 2007. Science \& Islam. Greenwood Press.

Khan, Muhammad Taqui-ud-Din Al Hilali and Muhammad Muhsin. 1996. Interpretation of the Meanings of the Noble Quran. Darussalam.

Khan, Sadullah. 2019. "Stewardship of Water, The Commodity of Life in Islami City." https://www.islamicity.org/7781/stewardship-of-water-the-commodity-of life/. 
Kushnir, Y. 2008. Solar Radiation and the Earth's Energy Balance. New York: Department of Earth and Environmental Sciences at Columbia University.

Lanza, L. G.., E. Vuerich and I. Gnecco. 2010. "Analysis of Highly Accurate Rain Intensity Measurements from A Field Test Site." Advances in Geosciences 25: 37-44.

Riddle, Cathy. 2016. "Why do Batteries Get Used Up and Go Dead?”. https://idahoaskascientist. com/2016/11/14/whydo-batteries-get-used-up-and-go-dead/.

Williams, Matt. 2014. “The Science of Heat Transfer: What Is Conduction?.” Universe Today.

Zotarelli, Lincoln., M. D. Dukes, C. C. Romero, K. W. Migliaccio and K. T. Morgan. 2018. One of a Series of the Agricultural and Biological Engineering Department. http:/ / edis.ifas.ufl.edu. 